It is to be hoped that further exploration of the data will continue, and that this monograph will not constitute the authors' final words on what is to be learnt from the study they have carried out so carefully.

\section{REFERENCES}

Liddell, F. D. K. (1963). An experiment in film reading. Brit. F. industr. Med., 20, 300-312.
- and May, Joan D. (1966). Assessing the Radiological Progression of Simple Pneumoconiosis. National Coal Board Medical Service (Medical Research Memorandum 4).

Wise, M. E., and Oldham, P. D. (1963). Estimating progression of coal-workers' simple pneumoconiosis from readings of radiological categories. Brit. $\mathcal{F}$. industr. Med., 20, 124-144.

\title{
Effect of 2,3-Dimercaptopropanol (BAL) on Urinary Excretion and Brain Content of Mercury
}

\author{
L. MAGOS \\ From the Toxicology Research Unit, M.R.C. Laboratories, Carshalton, Surrey
}

2,3-Dimercaptopropanol (BAL) given to rats in doses used for the treatment of acute mercury chloride poisoning in man increases the excretion of mercury. The mercury content of the brain was unaffected by 2,3-dimercaptopropanol unless it was given a short time after the mercuric chloride, when there was a $24 \%$ increase. The relevance of these findings to therapy with BAL is discussed.

2,3-Dimercaptopropanol (BAL) treatment of acute poisoning by mercury salts is sometimes regarded as contraindicated on the grounds that in certain circumstances it did not increase mercury excretion (Fitzsimmons and Kozelka, 1950; Berlin and Lewander, 1965) and did increase the concentration of mercury in the brain (Berlin and Lewander, 1965). In this paper I show that in rats therapeutic doses (recommended by the Extra Pharmacopoeia Martindale, 1967) increased mercury excretion and, unless given very shortly after the injection of mercuric chloride, did not increase the mercury content of the brain. The previous findings are wholly explicable by the use of doses lower than those used in man and by the timing of the therapy.

\section{Materials and Methods}

Female albino rats, Porton Wistar strain, of 200-240 g. body weight, were injected, intramuscularly into one thigh, with roo $\mu \mathrm{g}$. mercury as mercuric chloride labelled with ${ }^{203} \mathrm{Hg}$ to a specific activity of 3.5 or $7.5 \mu \mathrm{C} / \mathrm{mg}$. (Radiochemical Centre, Amersham, Bucks). BAL (Boots Pure Drug Co.) in $0.1 \mathrm{ml}$. arachis oil was given intramuscularly into the other thigh. When the urine and faeces were collected the animals were placed in metabolism cages. The animals were

Received for publication September I, 1967. killed by decapitation. The mercury content of the urine, faeces, and brain was estimated by counting ${ }^{203} \mathrm{Hg}$ with an automatic scintillation spectrometer (Model 50A, Packard Instrument $\mathrm{Co}$.) having a counting efficiency of $40 \%$.

\section{Results}

When BAL was given to rats six days after the administration of mercuric chloride a dose of 2 $\mathrm{mg} . / \mathrm{kg}$. had no effect on the urinary excretion of mercury, but doses of 8 and $16 \mathrm{mg} . / \mathrm{kg}$. markedly increased it. BAL in doses of $4 \mathrm{mg} . / \mathrm{kg}$. had a marginal effect on urinary excretion. The faecal excretion remained unchanged except after the highest dose which slightly increased it (Figure).

Table I shows that doses of 6 and $16 \mathrm{mg}$. $/ \mathrm{kg}$. given five days after the administration of mercuric chloride increased the urinary excretion but had no effect on the mercury content of the brain in the animals killed $24 \mathrm{hrs}$ after the injection of BAL.

However, when BAL $(6 \mathrm{mg}$. $/ \mathrm{kg}$.) was given 90 min. after the mercuric chloride and the treatment was repeated $5,25,30$, and $48 \mathrm{hrs}$ later there was an increase in the mercury content of the brain in the animals killed 24, 48, and 72 hrs after the first injection. Table II shows that the increase in the brain mercury content was only about $24 \%$ but the urinary excretion of mercury was 2.5 times higher in the BAL-treated than in the control animals. 


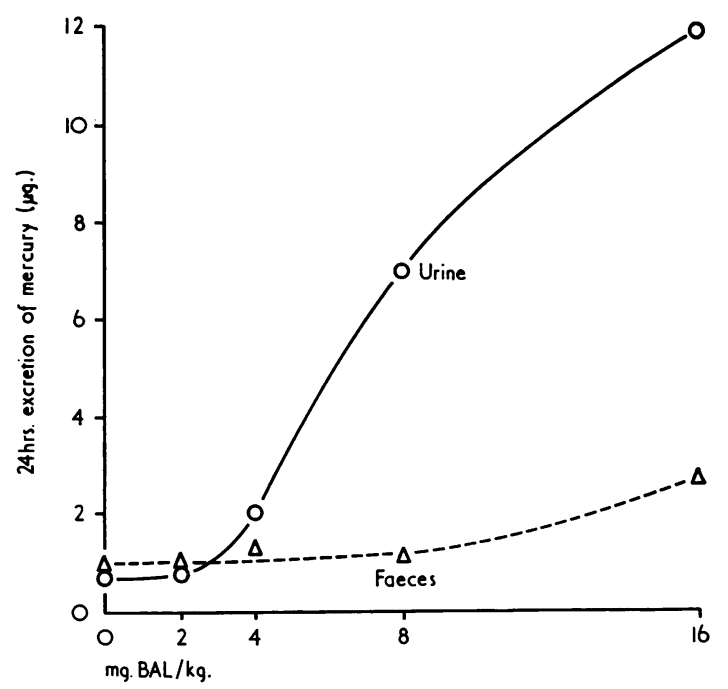

FIGURE The effect of different doses of BAL on urinary and faecal excretion. Four rats were treated with each dose.

\section{Discussion}

Longcope, Luetscher, Calkins, Grob, Bush, and Eisenberg (1946) and Moeschlin (1964) showed that BAL treatment was life-saving in acute cases of mercuric chloride poisoning. They gave doses of IO-I5 mg. $/ \mathrm{kg}$./day, comparable with the higher doses used in my experiments. Berlin and Lewander (1965) gave only $2 \mathrm{mg}$. $/ \mathrm{kg}$./day to mice, which is a far lower dose. At this dose rate excretion by rats is not increased (Figure). Fitzsimmons and Kozelka (1950) did not state what dose they used, but it seems probable that it was lower than that used in

\section{TABLE I}

EfFect of a Single Dose of BAL given 5 Days after the INJECTION OF IOO $\mu \mathrm{g}$. $\mathrm{Hg}$ AS $\mathrm{HgCl}_{2}$ ON THE URINARY EXCRETION AND BRAIN CONTENT OF MERCURY

\begin{tabular}{|c|c|c|c|}
\hline \multirow[t]{2}{*}{ Treatment } & \multirow[t]{2}{*}{ No. } & \multicolumn{2}{|c|}{ Mercury ( $\mu g)}$. \\
\hline & & Urine (24 hrs) & Brain \\
\hline None & 14 & $0.97( \pm 0.078)$ & $0.0520( \pm 0.0018)$ \\
\hline $\begin{array}{l}\text { BAL, } \\
6 \mathrm{mg} . / \mathrm{kg} .\end{array}$ & 12 & $3 \cdot 20^{1}( \pm 0.816)$ & $0.0523( \pm 0.0037)$ \\
\hline $\begin{array}{l}\text { BAL, } \\
16 \mathrm{mg} . / \mathrm{kg} .\end{array}$ & 12 & $14.74^{2}( \pm 0.864)$ & $0.0504( \pm 0.0024)$ \\
\hline
\end{tabular}

(The numbers in brackets are the standard errors). The animals were killed $24 \mathrm{hrs}$ after the BAL treatment.

$$
\begin{aligned}
& 10.02<P<0.025 \\
& 20.0005>>P
\end{aligned}
$$

TABLE II

URINARY EXCRETION AND BRAIN CONTENT OF MERCURY IN RATS WHEN BAL TREATMENT $(6.0 \mathrm{mg}$./kg. b.d.) WAS STARTED 90 MIN. AFTER THE MERCURY INJECTION

\begin{tabular}{c|c|c|c|c}
\hline \multirow{2}{*}{$\begin{array}{c}\text { Time after First } \\
\text { BAL Injection } \\
\text { (hrs) }\end{array}$} & $\begin{array}{c}\text { Brain Mercury } \\
\text { Content }(\mu g .)\end{array}$ & \multicolumn{2}{|c}{$\begin{array}{c}\text { Accumulated } \\
\text { Urinary Excretion } \\
(\mu g .)\end{array}$} \\
\cline { 2 - 5 } & Control & $\begin{array}{c}\text { BAL- } \\
\text { Treated }\end{array}$ & Control & $\begin{array}{c}\text { BAL- } \\
\text { Treated }\end{array}$ \\
\hline 24 & 0.030 & 0.039 & 1.50 & 2.53 \\
& 0.049 & 0.053 & 1.50 & \\
\hline 48 & 0.033 & 0.049 & 3.36 & 8.91 \\
\hline 72 & 0.041 & 0.061 & & \\
\hline & 0.039 & 0.048 & \\
& 0.041 & 0.050 & 4.88 & 12.06 \\
& 0.049 & 0.054 & & \\
\hline Average & 0.041 & 0.051 & & \\
\hline S.E.M. & 0.0025 & 0.0023 & & \\
\hline
\end{tabular}

man. There is, therefore, no inconsistency between the published data on animals and the effectiveness of BAL therapy. [Very high doses ( $50 \mathrm{mg}$. $/ \mathrm{kg}$.) have also been shown to accelerate the excretion of mercury from rats (Swensson and Ulfvarson, 1967)].

The mercury content of the brain was increased when BAL was given to the rats very shortly after the mercuric chloride (Table II), confirming Berlin and Lewander's report on mice. The increase in content was, however, only about $24 \%$. The relative unimportance of such an increase is illustrated by the work of Berlin, Jerksell, and von Ubisch (1966), who showed that when metallic mercury was given the brain content, as a fraction of the total body burden, was Io times greater than when a mercury salt was given.

The author wishes to thank Mr. R. Lock for technical assistance.

\section{REFERENCES}

Berlin, M., Jerksell, L. G., and von Ubisch, H. (1966). Uptake and retention of mercury in the mouse brain. Arch. environm. Hlth, 12, 33-42.

- , and Lewander, T. (1965). Increased brain uptake of mercury caused by 2,3-dimercaptopropanol (BAL) in mice given mercuric chloride. Acta pharmacol. (Kbh.), 22, I-7.

Extra Pharmacopoeia Martindale (1967). Ed. R. G. Todd, 25th ed., p. 543. The Pharmaceutical Press, London. 
Fitzsimmons, J. R., and Kozelka, F. L. (1950). Effects of BAL in tissue distribution and excretion of mercury in acute mercury poisoning. F. Pharmacol. exp. Ther., 98, 8.

Longcope, W. T., Luetscher, J. A., Jun, Calkins, E., Grob, D., Bush, S. W., and Eisenberg, H. (I946). Clinical uses of 2,3-dimercaptopropanol (BAL). XI. The treatment of acute mercury poisoning by BAL. F. clin. Invest., 25, 557-567.

Moeschlin, S. (1964). Klinik und Therapie der Vergiftungen, p. ro4. Thieme, Stuttgart.

Swensson, A., and Ulfvarson, U. (1967). Experiments with different antidotes in acute poisoning by different mercury compounds. Intern. Arch. Gewerbepath. Gewerbehyg., 24, $12-50$.

\title{
Stress Fracture of the Femur: A Work Accident
}

\author{
I. A. MANSOOR
}

From Rotschild Hospital, Haifa, Israel

Stress fracture has been well documented. Most cases reported occur in young conscripts of the armed forces (Bingham, 1945; Mann, 1945; Wolfe and Robertson, 1945). Other causes include the hard training programme of athletes, sport (Devas and Sweetnam, 1956; Kitchin, 1948; Devas, 1958; Miller, 1960; Devas, 1963), ballet dancing (Burrows, 1956), and ice-skating (Ingersoll, 1943). Presented here is a case of stress fracture of the femur caused by hard physical labour.

\section{Case History}

M.D., a casual labourer of 35 years of age, obtained employment during the construction of a building. His work entailed the continuous carrying of heavy loads from the ground to the upper floors. Three weeks after starting work he began to feel pain in the lower left thigh during work, which was at first relieved by rest. This gradually became worse and he sought medical advice on December 17, 1965. Radiographs were normal and a muscle strain was diagnosed. He continued working in order not to be discharged from the pay-roll. The pain became more persistent and severe until, by the end of a further three weeks, he could not bear weight fully on the leg, and limped. Three days before admission to hospital, on January 6, 1966, his left foot caught on the edge of a stair at home. He did not fall, but the pain suddenly became excruciating and he could bear no weight on it.

Examination showed the usual signs of fracture but without deformity. Radiographs (Fig. I) showed a fracture with minimal displacement.

Investigation showed: Hb 14.5 g. \%. W.B.C. 7,700/ c.mm. (band $4 \%$, segment $72 \%$, monocytes $6 \%$, lymphocytes $18 \%$ ); E.S.R. $32 \mathrm{~mm}$. in one hour (Westergren); urea $33 \mathrm{mg}$. $\%$; blood sugar I $18 \mathrm{mg}$. \%; total serum proteins 7 g. $\%$ (albumin 4 g. $\%$ ); acid phosphatase 0.3 unit, alkaline phosphatase 2.0 units; potassium 4.5 $\mathrm{mEq} / \mathrm{l}$., sodium $140 \mathrm{mEq} / \mathrm{l}$., chlorides $100 \mathrm{mEq} /$ litre.

He was given a single hip spica without anaesthesia

Received for publication October 26, 1967. and was discharged on January 14. His convalescence was uneventful and on March 6 he was allowed to bear weight on the plaster. On April 14 the plaster was removed. Clinically and radiologically (Fig. 2) the fracture had united.

\section{Discussion}

The insidious onset, the nature of his work, the trivial cause of the fracture, plus the lack of rotational deformity and little displacement occurring in a bone of normal texture and density, point to a diagnosis of stress fracture. Freiberger and Mayer (1964) report a case of bilateral stress fracture of the first rib in a plasterer who spent many hours plastering ceilings, holding a board of wet plaster in his left hand and a trowel in his right. This is the only other case of occupational stress fracture mentioned in the literature.

\section{REFERENCES}

Bingham, J. A. W. (1945). Stress fracture of femoral neck. Lancet, 2, 13-14.

Burrows, H. J. (1956). Fatigue fracture of the middle of the tibia in ballet dancers. $\mathcal{F}$. Bone $\mathcal{F}$ t Surg. 38B, 83-94.

Devas, M. B. (1958). Stress fractures of the tibia in athletes or 'shin soreness'. Ibid., 40B, 227-238.

- (1963). Stress fractures in children. Ibid., 45B, 528-54I. , and Sweetnam, R. (1956). Stress fractures of the fibula -a review of fifty cases in athletes. Ibid., 38B, 818-829.

Freiberger, R. H., and Mayer, V. (1964). Ununited bilateral fatigue fractures of the first ribs. Ibid., 46A, 615-618.

Ingersoll, C. F. (1943). Ice skater's fracture: a form of fatigue fracture. Amer. F. Roentgenol., 50, 469-479.

Kitchin, I. D. (1948). Fatigue fracture of the ulna. F. Bone ft Surg., 30B, 622-623.

Mann, T. P. (1945). Fatigue fracture of the tibia. Three cases at a Naval training establishment. Lancet, 2, 8-10.

Miller, J. E. (1960). Javelin thrower's elbow. f. Bone ft Surg., 42B, 788-792.

Wolfe, H. R. I., and Robertson, J. M. (1945). Fatigue fracture of femur and tibia (in young men undergoing intensive training). Lancet, 2, I I-13. 